\title{
Review Article \\ Recent Natural Corrosion Inhibitors for Mild Steel: An Overview
}

\author{
Marko Chigondo ${ }^{1}$ and Fidelis Chigondo ${ }^{2}$ \\ ${ }^{1}$ Department of Chemical and Processing Engineering, Manicaland College of Applied Sciences, Private Bag 9055, \\ Senga Road, Gweru, Zimbabwe \\ ${ }^{2}$ Department of Chemical Technology, Midlands State University, Private Bag 9055, Senga Road, Gweru, Zimbabwe \\ Correspondence should be addressed to Fidelis Chigondo; chigondofj@gmail.com
}

Received 11 March 2016; Accepted 26 June 2016

Academic Editor: Murat Senturk

Copyright (c) 2016 M. Chigondo and F. Chigondo. This is an open access article distributed under the Creative Commons Attribution License, which permits unrestricted use, distribution, and reproduction in any medium, provided the original work is properly cited.

\begin{abstract}
Traditionally, reduction of corrosion has been managed by various methods including cathodic protection, process control, reduction of the metal impurity content, and application of surface treatment techniques, as well as incorporation of suitable alloys. However, the use of corrosion inhibitors has proven to be the easiest and cheapest method for corrosion protection and prevention in acidic media. These inhibitors slow down the corrosion rate and thus prevent monetary losses due to metallic corrosion on industrial vessels, equipment, or surfaces. Inorganic and organic inhibitors are toxic and costly and thus recent focus has been turned to develop environmentally benign methods for corrosion retardation. Many researchers have recently focused on corrosion prevention methods using green inhibitors for mild steel in acidic solutions to mimic industrial processes. This paper provides an overview of types of corrosion, corrosion process, and mainly recent work done on the application of natural plant extracts as corrosion inhibitors for mild steel.
\end{abstract}

\section{Introduction}

Mild steel, also known as plain-carbon steel, is now the most common form of steel because its price is relatively low, while it provides material properties that are acceptable for many applications [1]. However, the challenge is that it has low corrosion resistance especially in acidic environments [2]. Industrial processes such as acid cleaning, pickling, descaling, and drilling operations in oil and gas exploration use acidic solutions extensively and as such iron and steel vessels or surfaces used in these environments are prone to corrosion [3]. The use of many inorganic inhibitors, particularly those containing phosphate, chromate, and other heavy metals, is now being gradually restricted or banned by various environmental regulations because of their toxicity and difficulties faced in their disposal especially in the marine industry, where aquatic life is at threat [4]. Synthetic organic inhibitors have also been extensively applied but their use is now being marred by their toxicity and high cost of manufacturing. This has prompted researchers to explore other areas to produce eco-friendly, cheap, and biodegradable green corrosion inhibitors to replace inorganic and synthetic organic inhibitors. Natural products such as plant extract, amino acids, proteins, and biopolymers have been reported to be efficient corrosion inhibitors [5]. Plant extracts are viewed as rich source of naturally synthesized chemical compounds that can be extracted by simple procedures with low cost [6]. These natural extracts are analogous to the synthetic organic inhibitors and are being proven to work as much as their synthetic counterparts. This review gives an overview of recent work on the inhibitive effect of various plant extracts particularly for mild steel in acidic medium so as to provide industrialists with vital comparative literature for possible large scale use of natural inhibitors in their operations. This will contribute to sustainable and green manufacturing. The effects of temperature, concentration, and reaction medium on the inhibition efficiency were compared. Methods used for studying corrosion and the adsorption isotherms deduced are also highlighted.

\section{Types of Corrosion}

Corrosion is defined as the deterioration of a substance or its properties due to interactions between the substance and its 
TABLE 1: Types of corrosion.

\begin{tabular}{ll}
\hline Type of corrosion & Description \\
\hline $\begin{array}{l}\text { Uniform corrosion } \\
\text { Galvanic corrosion }\end{array}$ & $\begin{array}{l}\text { Deteriorates the whole surface of the metal and makes the surface thin. } \\
\text { Occurs with an electrolyte with metals having different values of electrical potentials. } \\
\text { Pitting corrosion }\end{array}$ \\
$\begin{array}{l}\text { Occurs because of random attacks on particular parts of the metal's surface to form pits. The } \\
\text { pit acts as the anode, while the undamaged part of the metal is the cathode. }\end{array}$ \\
$\begin{array}{l}\text { A complex form of corrosion which arises due to stress and corrosive environment. } \\
\text { Intergranular corrosion }\end{array}$ \\
A combination of cyclic stress and corrosion. \\
Crevice corrosion & $\begin{array}{l}\text { Corrosion occurs on or near the grain boundaries of a metal. } \\
\text { metal. }\end{array}$ \\
Filiform corrosion & $\begin{array}{l}\text { Concentration cell corrosion on metallic surfaces coated with a thin organic film. } \\
\text { Erosion corrosion }\end{array}$ \\
Fretting corrosion & $\begin{array}{l}\text { A form of erosisted corrosion which is due to the movement of corrosive liquids on metal surface. } \\
\text { metal. }\end{array}$ \\
\hline
\end{tabular}

environment [7]. The tendency of a metal to corrode depends on the grain structure of the metal, its composition as formed during alloying, or the temperature for deformation of a single metal surface developed during fabrication. Corrosion prevention would be more practical than trying to eliminate it completely. Given that the environment plays an important part in corrosion, corrosion mechanisms can be as varied as the environments to which a substance is exposed and thus may be complex to understand. Factors that cause corrosion include reactivity of metal, presence of impurities, presence of air, moisture, gases like sulphur dioxide and carbon dioxide, and presence of electrolytes. Corrosion prevention and retardation are aimed at addressing these factors [8].

The different types of corrosion which depend on the environment surrounding the material, type of material, or chemical reaction are briefly described in Table 1 [9].

\section{Corrosion Prevention Processes}

The protection of materials especially steel structures from corrosion is achieved by basically two methods, namely, cathodic protection and the use of corrosion inhibitors. Cathodic protection to a metal structure can be done by either the technique of impressed current or using a sacrificial anode. Cathodic protection is achieved by making a metal to work as a cathode in an electrochemical cell. Sacrificial anodes are highly active metals with more negative electrochemical potential than the other metal which they are used to protect. Thus sacrificial anodes are consumed in place of the metal they protect. Impressed cathodic protection is obtained during the stage, where open circuit potential of cathodic sites gets polarized into the same circuits' potential of anodic sites and thus makes the whole circuit cathodic in nature to prevent corrosion [8].

Among these methods, corrosion inhibition is the most economical, practical, and convenient technique to control corrosion on metals in aqueous environment [10]. Corrosion inhibitors control the metal dissolution as well as the acid consumption. Inhibitors are adsorbed on the metal surface, forming a protective barrier, and interact with anodic or/and cathodic reaction sites to decrease the oxidation or/and reduction of corrosion reactions [11]. Most of the well-known inhibitors are organic compounds containing electronegative functional groups and $\pi$-electrons in conjugated double or triple bonds and hence exhibit good inhibitive properties by supplying electrons through $\pi$-orbitals [12]. There is also a specific interaction between functional groups containing heteroatoms like nitrogen, sulfur, oxygen having free lone pair of electrons, and the metal surface, which play an important role in inhibition. When both of these features combine, increased inhibition can be observed [13].

\section{Synthetic Organic Corrosion Inhibitors}

Synthetic compounds containing multiple bonds and heteroatoms are effective inhibitors, but at the same time the processing time, cost, and their toxic nature have compelled researchers to look for alternatives [6]. The inhibiting effect of some of these synthetic organic compounds on the corrosion of mild steel has been recently reported by several authors $[1,5,10,12-20]$. However, most of the compounds that constitute these inhibitors are expensive and toxic to human and the environment. The toxicity of these organic inhibitors has paved way to explore the use of nontoxic natural products inhibitors that are environmentally friendly and biodegradable.

\section{Some Active Ingredients in Green Corrosion Inhibitors for Mild Steel}

Plant extracts have potential to replace synthetic organic and inorganic inhibitors given their success story in literature. The mechanism of action of green inhibitors depends on the structure of the active ingredient and thus many researchers have to date postulated many theories to explain this phenomenon [12]. One suggestion is that the active compounds form onium ions in acidic solutions and are 


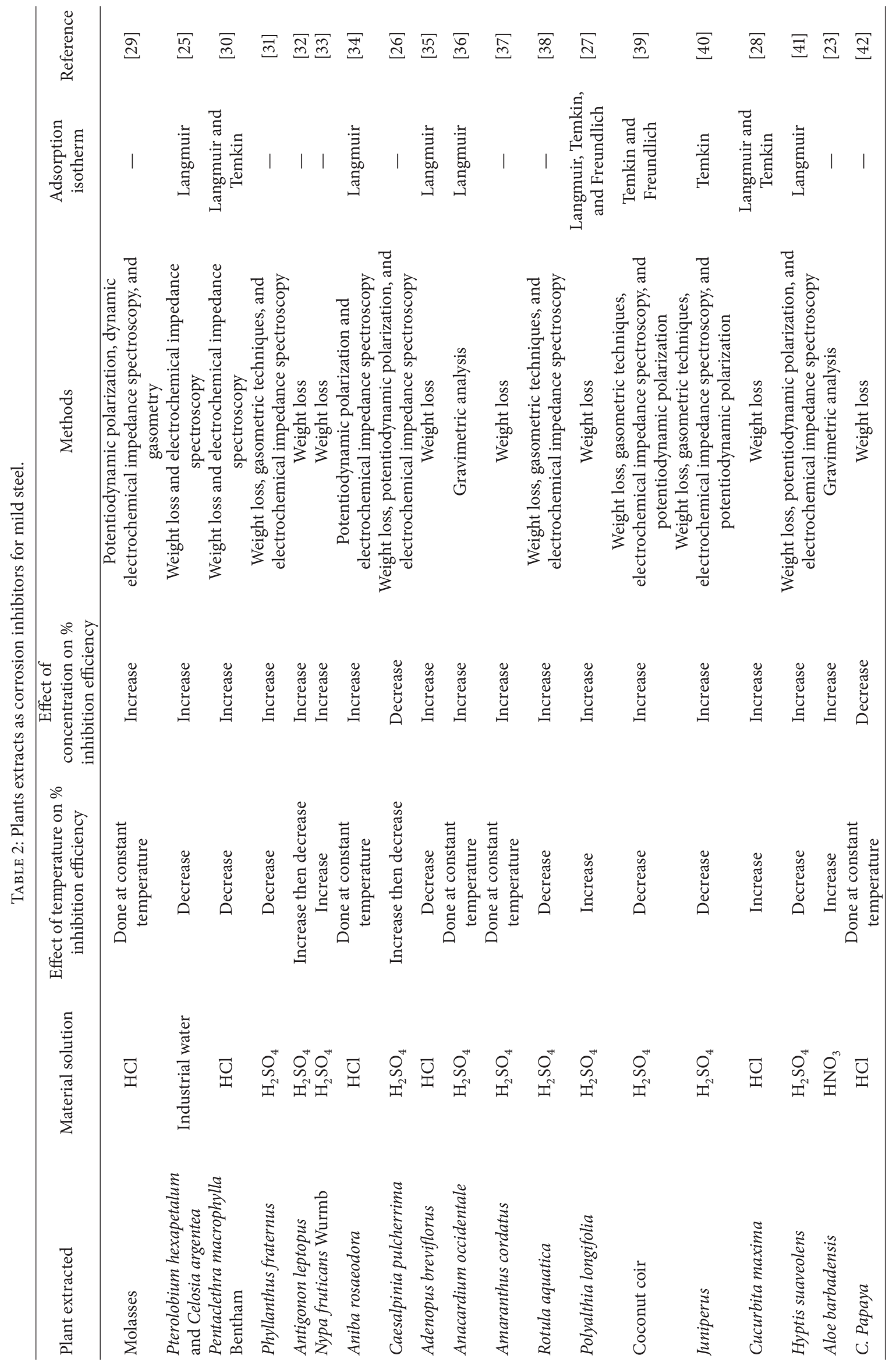




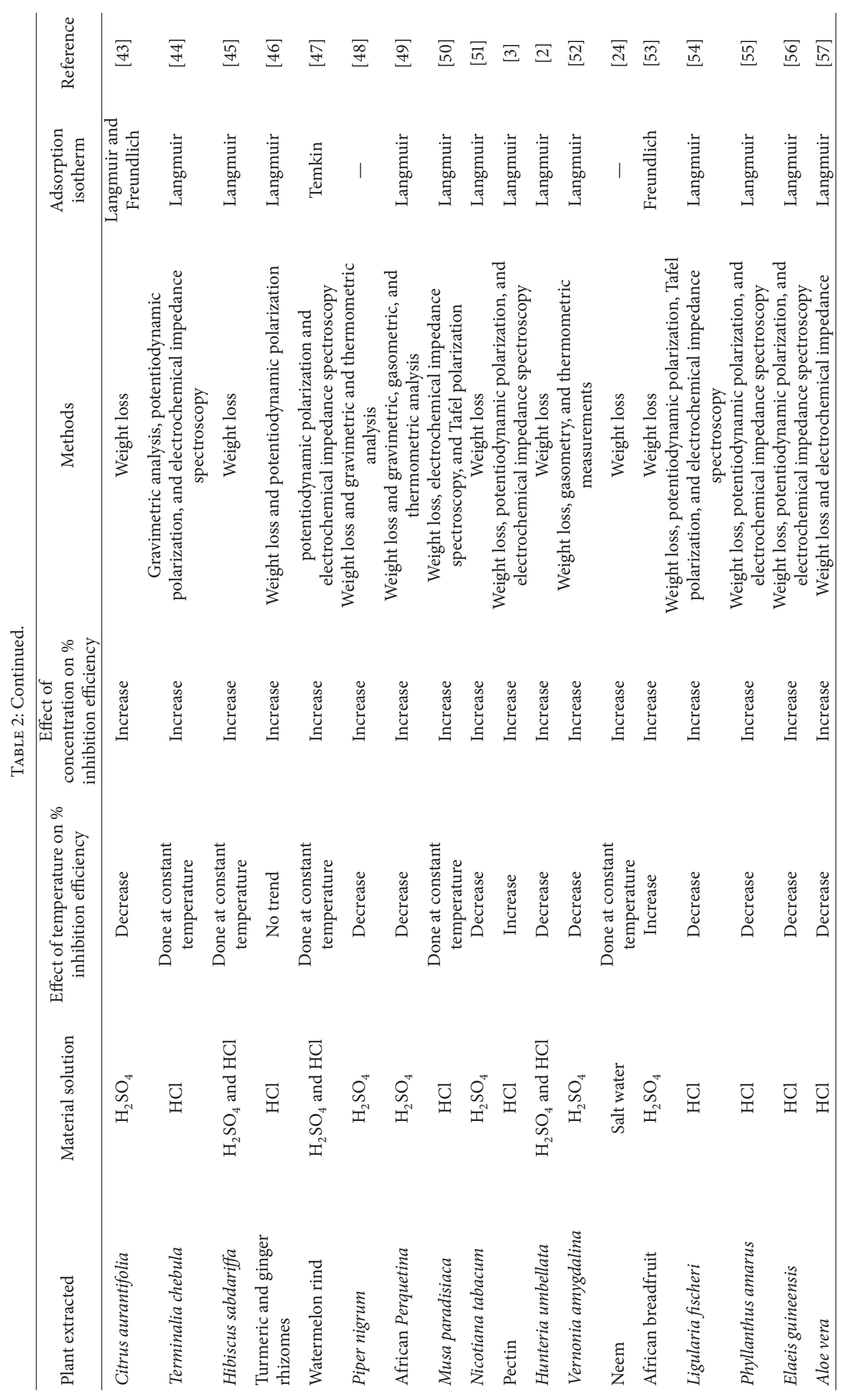


adsorbed on the cathodic sites of the metal surface and interfere with the cathodic reaction [21]. The active constituents of natural inhibitors vary from one plant species to another but their structures are closely related to their organic counterparts. For example, garlic contains allyl propyl disulphide, mustard seeds contain an alkaloid berberine which has a long chain of aromatic rings and an $\mathrm{N}$ atom in the ring, and, at several places, carrot contains pyrrolidine and castor seed contains the alkaloid ricinine. Eucalyptus oil contains monomtrene-1,8-cineole. Lawsonia extract contains 2-hydroxy-1,4-naphthoquinone resin and tannin, coumarin, gallic acid, and sterols. Gum exudate contains hexuronic acid, neutral sugar residues, volatile monoterpenes, canaric and related triterpene acids, and reducing and nonreducing sugars. Garcinia kola seed contains primary and secondary amines, unsaturated fatty acids, and bioflavonoids. Calyx extract contains ascorbic acid, amino acids, flavonoids, pigments, and carotene [21].

\section{Plant Extracts as Corrosion Inhibitors for Mild Steel}

The adsorption of natural corrosion inhibitors on metal surfaces is influenced by a number of factors including nature of metal, testing media, chemical structure of inhibitor, nature of substituents present in the inhibitor, presence of additives, solution temperature, and solution concentration [22]. Recent studies by various authors on the inhibition of mild steel by plant extracts are shown in Table 2 .

It can be observed from the reviewed summarized literature in the table that there has been active research on the application of plant extracts as green corrosion inhibitors for mild steel for the period of about two years reviewed. The analysis of the review summary above in Table 2 is thus presented below.

6.1. Corrosion Media. The research was mainly conducted in sulphuric acid and hydrochloric acid and in some cases in both media and thus covered fair representation of real industrial scenarios, where steel exposed to these acids is used. It is interesting to note that nitric acid [23] and salt [24] media were also explored although in isolated cases. The research conducted in the industrial effluent [25] medium shows that the application of green corrosion inhibitors in real effluent is beginning to show up and this may lead to large scale implementation.

6.2. Effect of Increasing Inhibitor Concentration and Temperature of Inhibition Efficiency. The effect of increasing concentration of inhibitor resulted in increase in inhibition efficiency for all studies except an extract from Caesalpinia pulcherrima [26], where inhibition efficient increases with decrease in inhibitor concentration. This is encouraging because it means green inhibitors can be used in low concentration, thus making them cheaper and eco-friendly. The inhibition efficiency decreased with an increase in temperature in most cases, thus proving that the process is efficient at room temperature or low temperatures. In some few cases $[3,23,27,28]$, inhibition efficiency was high at high temperature and this can be an advantage, where mild steel is used in high temperature applications.

6.3. Methods Used for Studying Inhibition Efficiency, Inhibitor Type, and Adsorption Process. In all cases, the weight loss method was employed in measuring inhibition efficiency. The other popular method was gravimetric analysis. Potentiodynamic polarization and electrochemical impedance spectroscopy were mostly used in deducing inhibitor type and adsorption process. Tafel polarization and gasometric, thermometric methods were also used in addition to the above in some few cases. The adsorption of plant extracts and acid ions on the surface of mild steel in the majority of the studies followed the Langmuir isotherm model.

\section{Conclusion}

From the above discussion, it is quite obvious that natural plant extracts are effective green corrosion inhibitors against mild steel. Weight loss, electrochemical impedance, and potentiodynamic polarization techniques were mainly used to confirm corrosion inhibition mainly in sulphuric acid or hydrochloric acid media. A lot of potential is still untapped especially computational modelling of the major extract components on mild steel. This will help in establishing detailed mechanisms for corrosion inhibition. Work on the studies of real industrial effluent or real life situations is limited. There is need for further work on the exploration of these plant materials in other corrosive environments such as carbon dioxide, sulphur dioxide, and hydrogen sulfide. Further research should also be focused on the extraction and structural elucidation of active plants extracts to ascertain the structure of these compounds so as to help understand the process of corrosion inhibition. Scale-up experiments for industrial applications also need to be done so as to commercialize these natural extracts to effectively replace the conventional chemicals currently used to control corrosion.

\section{Competing Interests}

The authors declare that there are no competing interests regarding the publication of this paper.

\section{References}

[1] D. K. Singh, S. Kumar, G. Udayabhanu, and R. P. John, “4(N,Ndimethylamino) benzaldehyde nicotinic hydrazone as corrosion inhibitor for mild steel in $1 \mathrm{M} \mathrm{HCl}$ solution: An experimental and theoretical study," Journal of Molecular Liquids, vol. 216, pp. 738-746, 2016.

[2] K. K. Alaneme, S. J. Olusegun, and O. T. Adelowo, "Corrosion inhibition and adsorption mechanism studies of Hunteria umbellata seed husk extracts on mild steel immersed in acidic solutions," Alexandria Engineering Journal, vol. 55, no. 1, pp. 673-681, 2016.

[3] M. V. Fiori-Bimbi, P. E. Alvarez, H. Vaca, and C. A. Gervasi, "Corrosion inhibition of mild steel in HCL solution by pectin," Corrosion Science, vol. 92, pp. 192-199, 2015. 
[4] P. Roy, P. Karfa, U. Adhikari, and D. Sukul, "Corrosion inhibition of mild steel in acidic medium by polyacrylamide grafted Guar gum with various grafting percentage: effect of intramolecular synergism," Corrosion Science, vol. 88, pp. 246253, 2014.

[5] G. Sığırcık, T. Tüken, and M. Erbil, "Assessment of the inhibition efficiency of 3,4-diaminobenzonitrile against the corrosion of steel," Corrosion Science, vol. 102, pp. 437-445, 2016.

[6] K. Krishnaveni and J. Ravichandran, "Effect of aqueous extract of leaves of Morinda tinctoria on corrosion inhibition of aluminium surface in $\mathrm{HCl}$ medium," Transactions of Nonferrous Metals Society of China, vol. 24, no. 8, pp. 2704-2712, 2014.

[7] I. Adejoro, F. Ojo, and S. Obafemi, "Corrosion inhibition potentials of ampicillin for mild steel in hydrochloric acid solution," Journal of Taibah University for Science, vol. 9, no. 2, pp. 196-202, 2015.

[8] V. S. Sastri, "Corrosion processes and the use of corrosion inhibitors in managing corrosion in underground pipelines," in Underground Pipeline Corrosion: Cathodic Protection and High Efficiency Coating, pp. 127-165, 2014.

[9] R. Singh, "Corrosion control and monitoring," in Corrosion Control for Offshore Structures: Cathodic Protection and High Efficiency Coating, pp. 41-44, 2014.

[10] M. M. Solomon and S. A. Umoren, "Enhanced corrosion inhibition effect of polypropylene glycol in the presence of iodide ions at mild steel/sulphuric acid interface," Journal of Environmental Chemical Engineering, vol. 3, no. 3, pp. 1812-1826, 2015.

[11] P. Singh, V. Srivastava, and M. A. Quraishi, "Novel quinoline derivatives as green corrosion inhibitors for mild steel in acidic medium: electrochemical, SEM, AFM, and XPS studies," Journal of Molecular Liquids, vol. 216, pp. 164-173, 2016.

[12] M. Yadav, L. Gope, N. Kumari, and P. Yadav, "Corrosion inhibition performance of pyranopyrazole derivatives for mild steel in $\mathrm{HCl}$ solution: gravimetric, electrochemical and DFT studies," Journal of Molecular Liquids, vol. 216, pp. 78-86, 2016.

[13] A. Dutta, S. K. Saha, P. Banerjee, and D. Sukul, "Correlating electronic structure with corrosion inhibition potentiality of some bis-benzimidazole derivatives for mild steel in hydrochloric acid: combined experimental and theoretical studies," Corrosion Science, vol. 98, pp. 541-550, 2015.

[14] A. Popova, M. Christov, and A. Vasilev, "Mono- and dicationic benzothiazolic quaternary ammonium bromides as mild steel corrosion inhibitors. Part III: influence of the temperature on the inhibition process," Corrosion Science, vol. 94, pp. 70-78, 2015.

[15] M. Yadav, R. R. Sinha, S. Kumar, I. Bahadur, and E. E. Ebenso, "Synthesis and application of new acetohydrazide derivatives as a corrosion inhibition of mild steel in acidic medium: insight from electrochemical and theoretical studies," Journal of Molecular Liquids, vol. 208, no. 4822, pp. 322-332, 2015.

[16] J. Saranya, P. Sounthari, K. Parameswari, and S. Chitra, "Acenaphtho[1,2-b]quinoxaline and acenaphtho[1,2-b]pyrazine as corrosion inhibitors for mild steel in acid medium," Measurement, vol. 77, pp. 175-185, 2016.

[17] B. Xu, Y. Ji, X. Zhang, X. Jin, W. Yang, and Y. Chen, "Experimental and theoretical evaluation of $\mathrm{N}, \mathrm{N}-\mathrm{Bis}(2-$ pyridylmethyl)aniline as a novel corrosion inhibitor for mild steel in hydrochloric acid," Journal of the Taiwan Institute of Chemical Engineers, vol. 59, pp. 526-535, 2016.
[18] P. Mourya, P. Singh, R. B. Rastogi, and M. M. Singh, "Inhibition of mild steel corrosion by 1,4,6-trimethyl-2-oxo-1,2dihydropyridine-3-carbonitrile and synergistic effect of halide ion in $0.5 \mathrm{M} \mathrm{H}_{2} \mathrm{SO}_{4}$," Applied Surface Science, vol. 380, pp. 141150, 2016.

[19] D. Zhang, Y. Tang, S. Qi, D. Dong, H. Cang, and G. Lu, "The inhibition performance of long-chain alkyl-substituted benzimidazole derivatives for corrosion of mild steel in $\mathrm{HCl}$," Corrosion Science, vol. 102, pp. 517-522, 2016.

[20] N. Kıcır, G. Tansuğ, M. Erbil, and T. Tüken, "Investigation of ammonium (2,4-dimethylphenyl)-dithiocarbamate as a new, effective corrosion inhibitor for mild steel," Corrosion Science, vol. 105, pp. 88-99, 2016.

[21] B. E. A. Rani and B. B. J. Basu, "Green inhibitors for corrosion protection of metals and alloys: an overview," International Journal of Corrosion, vol. 2012, Article ID 380217, 15 pages, 2012.

[22] C. Verma and M. A. Quraishi, "Adsorption behavior of 8,9-bis (4 (dimethyl amino)phenyl)benzo[4,5]imidazo[1,2-a]pyridine6,7-dicarbonitrile on mild steel surface in $1 \mathrm{M} \mathrm{HCl,"} \mathrm{Journal}$ of the Association of Arab Universities for Basic and Applied Sciences, 2016.

[23] G. Pankaj and J. Gargi, "Corrosion inhibition by Aloe Barbadensis (Aloe vera) extract as green inhibitor for mild steel in $\mathrm{HNO}_{3}$," International Journal of Scientific Research and Reviews, vol. 3, pp. 72-83, 2014.

[24] T. J. Tuaweri, E. A. Ogbonnaya, and O. O. Onyemaobi, "Corrosion inhibition of heat treated mild steel with neem leave extract in a chloride medium," International Journal of Research in Engineering and Technology, vol. 4, no. 6, pp. 404-409, 2015.

[25] C. P. P. Kumar and K. N. Mohana, "Phytochemical screening and corrosion inhibitive behavior of Pterolobium hexapetalum and Celosia argentea plant extracts on mild steel in industrial water medium," Egyptian Journal of Petroleum, vol. 23, no. 2, pp. 201-211, 2014.

[26] K. Kanagavalli, T. Sathyyariya, and G. Rathika, "Caesalpinia pulcherrima as corrosion inhibitor for mild steel in acid medium," International Journal of Scientific and Engineering Research, vol. 5, no. 10, pp. 1411-1416, 2014.

[27] V. G. Vasudha and K. S. Priya, "Corrosion inhibition of mild steel in $\mathrm{H}_{2} \mathrm{SO}_{4}$ media using Polyalthia longifolia leaves," Chemical Science Review and Letters, vol. 2, no. 6, pp. 435-443, 2014.

[28] K. Anbarasi and V. G. Vasudha, "Corrosion inhibition potential of Cucurbita maxima plant extract on mild steel in acid media," Chemical Science Review and Letters, vol. 3, no. 9, pp. 45-51, 2014.

[29] P. Slepski, H. Gerengi, A. Jazdzewska, J. Orlikowski, and K. Darowicki, "Simultaneous impedance and volumetric studies and additionally potentiodynamic polarization measurements of molasses as a carbon steel corrosion inhibitor in $1 \mathrm{M}$ hydrochloric acid solution," Construction and Building Materials, vol. 52, pp. 482-487, 2014.

[30] L. A. Nnanna, I. O. Owate, and E. E. Oguzie, "Inhibition of mild steel corrosion in $\mathrm{HCl}$ solution by Pentaclethra macrophylla Bentham extract," International Journal of Materials Engineering, vol. 4, no. 5, pp. 171-179, 2014.

[31] N. S. Patel, J. Hrdlicka, P. Beranek et al., "Extract of Phyllanthus fraternus leaves as corrosion inhibitor for mild steel in $\mathrm{H}_{2} \mathrm{SO}_{4}$ solutions," International Journal of Electrochemical Science, vol. 9, no. 6, pp. 2805-2815, 2014.

[32] S. Aejitha, P. K. Asthuri, and Geethamani, "Inhibition effect of Antigonon leptopus extract on mild steel in sulphuric acid 
medium," Indian Journal of Applied Research, vol. 4, no. 12, pp. 51-53, 2014.

[33] N. C. Michael and J. A. Olubunmi, "The corrosion inhibition of mild steel in sulphuric acid solution by flavonoid (catechin) separated from nypa fruticans wurmb leaves extract," Science Journal of Chemistry, vol. 2, no. 4, pp. 27-32, 2014.

[34] M. Chevalier, F. Robert, N. Amusant, M. Traisnel, C. Roos, and M. Lebrini, "Enhanced corrosion resistance of mild steel in $1 \mathrm{M}$ hydrochloric acid solution by alkaloids extract from Aniba rosaeodora plant: electrochemical, phytochemical and XPS studies," Electrochimica Acta, vol. 131, pp. 96-105, 2014.

[35] A. Adewuyi, A. Göpfert, and T. Wolff, "Succinyl amide gemini surfactant from Adenopus breviflorus seed oil: A potential corrosion inhibitor of mild steel in acidic medium," Industrial Crops and Products, vol. 52, pp. 439-449, 2014.

[36] D. E. Arthur, A. Adedayo, G. Igelige, and E. Ogwuche, "Corrosion inhibition of mild steel in $0.1 \mathrm{M} \mathrm{H}_{2} \mathrm{SO}_{4}$ solution by Anacardium occidentale gum," American Chemical Science Journal, vol. 4, no. 6, pp. 847-854, 2014.

[37] M. O. Nwankwo, P. O. Offor, S. I. Neife, L. C. Oshionwu, and N. E. Idenyi, "Amaranthus cordatus as a green corrosion inhibitor for mild steel in $\mathrm{H}_{2} \mathrm{SO}_{4}$ and $\mathrm{NaCl}$," Journal of Minerals and Materials Characterization and Engineering, vol. 2, no. 3, pp. 194-199, 2014.

[38] N. S. Patel, J. Hadlicka, P. Beranek et al., "Corrosion inhibition of steel by various parts of rotula aquatica plant extracts in $\mathrm{H}_{2} \mathrm{SO}_{4}$ solutions," Portugaliae Electrochimica Acta, vol. 32, no. 6, pp. 395-403, 2014.

[39] S. A. Umoren, I. B. Obot, A. U. Israel et al., "Inhibition of mild steel corrosion in acidic medium using coconut coir dust extracted from water and methanol as solvents," Journal of Industrial and Engineering Chemistry, vol. 20, no. 5, pp. 36123622, 2014.

[40] S. R. Al-Mhyawi, "Inhibition of mild steel corrosion using Juniperus plants as green inhibitior," African Journal of Pure and Applied Chemistry, vol. 8, no. 1, pp. 9-22, 2014.

[41] P. Muthukrishnan, B. Jeyaprabha, and P. Prakash, "Mild steel corrosion inhibition by aqueous extract of Hyptis suaveolens leaves," International Journal of Industrial Chemistry, vol. 5, no. 1, article 5, pp. 1-11, 2014.

[42] N. Kavitha, P. Manjula, and N. Anandha, "Syneristic effect of $C$. Papaya leaves extract- $\mathrm{Zn}^{2+}$ in corrosion inhibition of mild steel in aqueous medium," Research Journal of Chemical Science, vol. 4, no. 8, pp. 88-93, 2014.

[43] K. C. Ajani, A. S. Abdulrahman, and E. Mudiare, "Inhibitory action of aqueous Citrus aurantifolia seed extract on the corrosion of mild steel in $\mathrm{H}_{2} \mathrm{SO}_{4}$ Solution," World Applied Sciences Journal, vol. 31, no. 12, pp. 2141-2147, 2014.

[44] E. E. Oguzie, M. A. Chidiebere, K. L. Oguzie, C. B. Adindu, and H. Momoh-Yahaya, "Biomass extracts for materials protection: corrosion inhibition of mild steel in acidic media by Terminalia chebula extracts," Chemical Engineering Communications, vol. 201, no. 6, pp. 790-803, 2014.

[45] Z. V. P. Murthy and K. Vijayaragavan, "Mild steel corrosion inhibition by acid extract of leaves of Hibiscus sabdariffa as a green corrosion inhibitor and sorption behavior," Green Chemistry Letters and Reviews, vol. 7, no. 3, pp. 209-219, 2014.

[46] A. M. Al-Fakih, M. Aziz, and H. M. Sirat, "Turmeric and ginger as green inhibitors of mild steel corrosion in acidic medium," Journal of Materials and Environmental Science, vol. 6, no. 5, pp. 1480-1487, 2015.
[47] N. A. Odewunmi, S. A. Umoren, and Z. M. Gasem, "Utilization of watermelon rind extract as a green corrosion inhibitor for mild steel in acidic media," Journal of Industrial and Engineering Chemistry, vol. 21, pp. 239-247, 2015.

[48] N. Mohd and A. S. Ishak, "Thermodynamic study of corrosion inhibition of mild steel in corrosive medium by Piper nigrum extract," Indian Journal of Science and Technology, vol. 8, no. 17, Article ID 63478, pp. 1-7, 2015.

[49] A. S. Abdulrahman, K. A. Ganiyu, I. H. Kobe, and A. I. Caroline, "The corrosion inhibition of mild steel in sulphuric acid solution by adsorption of African Perquetina leaves extract," International Journal of Innovative Research in Science, Engineering and Technology, vol. 4, no. 4, pp. 1809-1821, 2015.

[50] G. Ji, S. Anjum, S. Sundaram, and R. Prakash, “Musa paradisica peel extract as green corrosion inhibitor for mild steel in $\mathrm{HCl}$ solution," Corrosion Science, vol. 90, pp. 107-117, 2015.

[51] J. Bhawsar, P. K. Jain, and P. Jain, "Experimental and computational studies of Nicotiana tabacum leaves extract as green corrosion inhibitor for mild steel in acidic medium," Alexandria Engineering Journal, vol. 54, no. 3, pp. 769-775, 2015.

[52] A. I. Caroline, A. S. Abdulrahaman, I. H. Kobe, K. A. Ganiyu, and S. M. Adams, "Inhibitive performance of bitter leaf root extract on mild steel corrosion in sulphuric acid solution," American Journal of Materials Engineering and Technology, vol. 3, no. 2, pp. 35-45, 2015.

[53] P. M. Ejikeme, S. G. Umana, M. C. Menkiti, and O. D. Onukwuli, "Inhibition of mild steel and aluminium corrosion in $1 \mathrm{M} \mathrm{H}_{2} \mathrm{SO}_{4}$ by leaves extract of African Breadfruit," International Journal of Materials and Chemistry, vol. 5, no. 1, pp. 14-23, 2015.

[54] M. Prabakaran, S.-H. Kim, K. Kalaiselvi, V. Hemapriya, and I.M. Chung, "Highly efficient Ligularia fischeri green extract for the protection against corrosion of mild steel in acidic medium: electrochemical and spectroscopic investigations," Journal of the Taiwan Institute of Chemical Engineers, vol. 59, pp. 553-562, 2016.

[55] K. K. Anupama, K. Ramya, and A. Joseph, "Electrochemical and computational aspects of surface interaction and corrosion inhibition of mild steel in hydrochloric acid by Phyllanthus amarus leaf extract (PAE)," Journal of Molecular Liquids, vol. 216, pp. 146-155, 2016.

[56] M. H. Hussin, A. A. Rahim, M. N. M. Ibrahim, and N. Brosse, "The capability of ultrafiltrated alkaline and organosolv oil palm (Elaeis guineensis) fronds lignin as green corrosion inhibitor for mild steel in $0.5 \mathrm{M} \mathrm{HCl}$ solution," Measurement, vol. 78, pp. 90103, 2016.

[57] A. K. Singh, S. Mohapatra, and B. Pani, "Corrosion inhibition effect of Aloe vera gel: gravimetric and electrochemical study," Journal of Industrial and Engineering Chemistry, vol. 33, pp. 288297, 2016. 

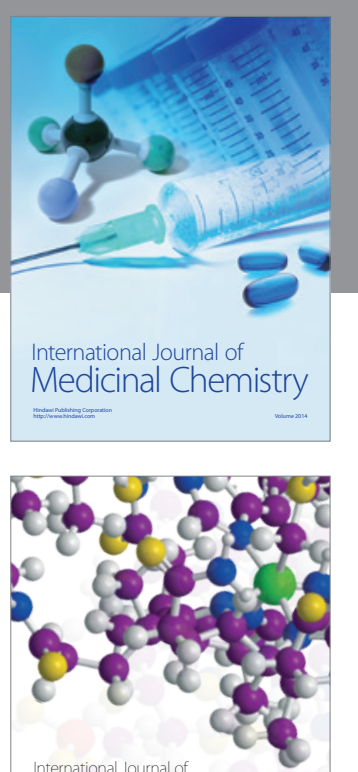

Carbohydrate Chemistry

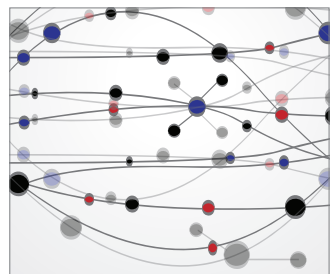

The Scientific World Journal
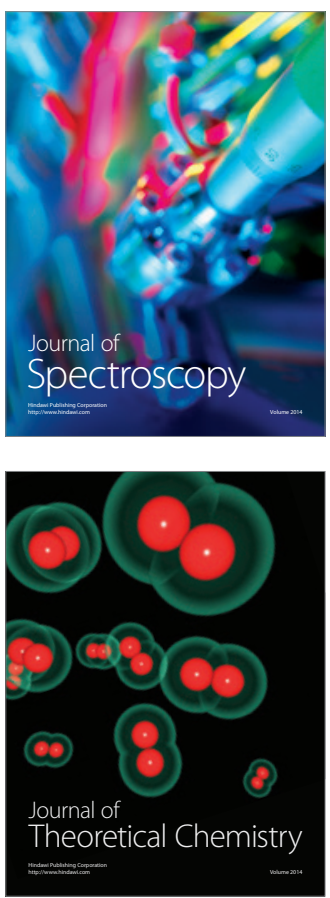
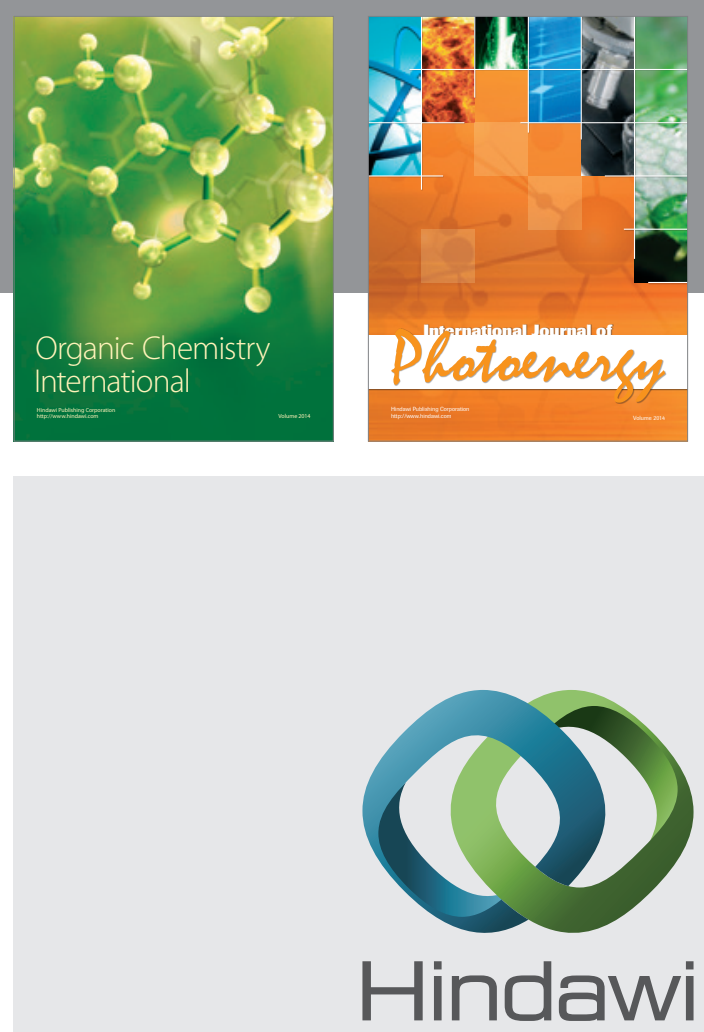

Submit your manuscripts at

http://www.hindawi.com

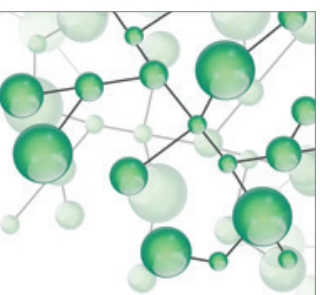

International Journal of

Inorganic Chemistry

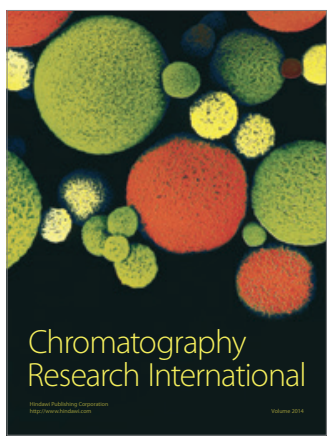

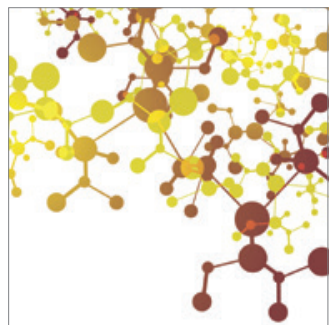

Applied Chemistry
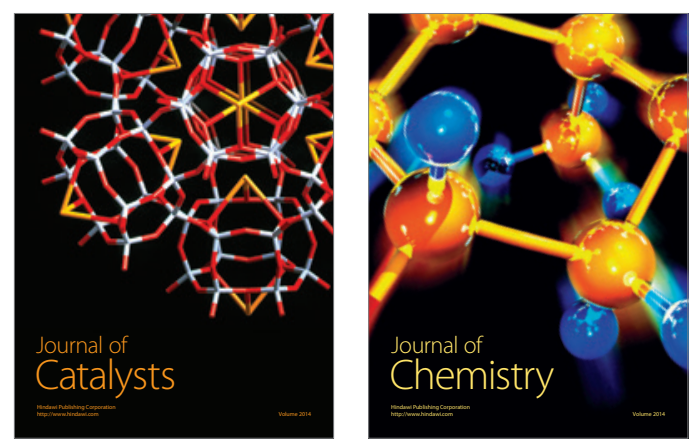
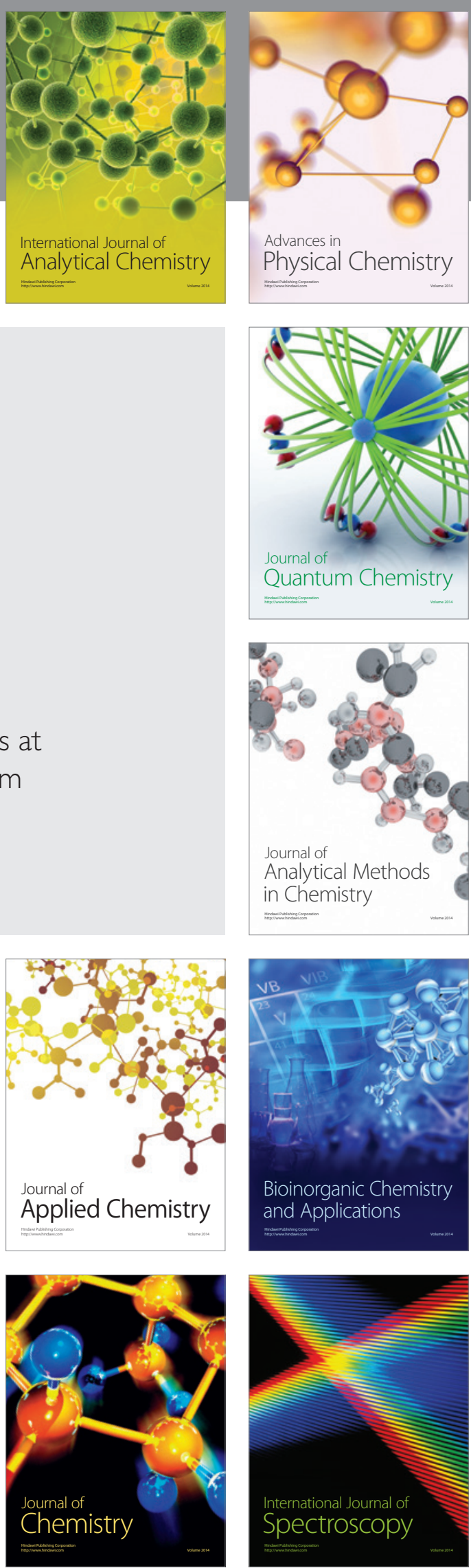